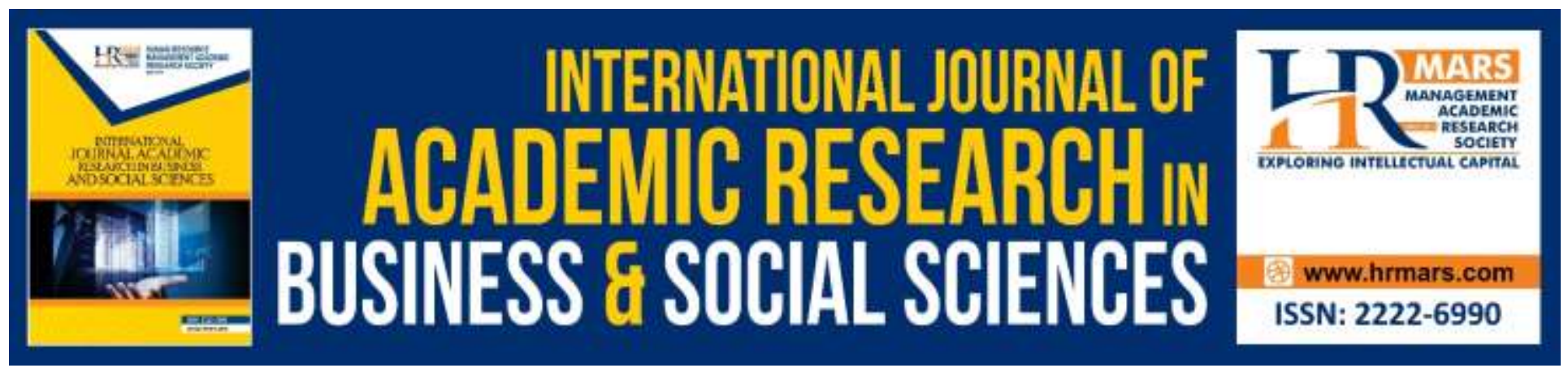

\title{
The Usage of Interactive Multimedia- Based Modules to Improve Students' Vocabulary
}

\section{Tracy Valerian, Norjietta Binti Taisin}

To Link this Article: http://dx.doi.org/10.6007/IJARBSS/v10-i6/7379

DOI:10.6007/IJARBSS/v10-i6/7379

Received: 16 April 2020, Revised: 20 May 2020, Accepted: 14 June 2020

Published Online: 23 June 2020

In-Text Citation: (Valerian \& Taisin, 2020)

To Cite this Article: Valerian, T., \& Taisin, N. B. (2020). The Usage of Interactive Multimedia- Based Modules to Improve Students' Vocabulary. International Journal of Academic Research in Business and Social Sciences, 10(6), 856-861.

\section{Copyright: (C) 2020 The Author(s)}

Published by Human Resource Management Academic Research Society (www.hrmars.com)

This article is published under the Creative Commons Attribution (CC BY 4.0) license. Anyone may reproduce, distribute, translate and create derivative works of this article (for both commercial and non-commercial purposes), subject to full attribution to the original publication and authors. The full terms of this license may be seen

at: http://creativecommons.org/licences/by/4.0/legalcode

\section{Vol. 10, No. 6, 2020, Pg. 856 - 861}




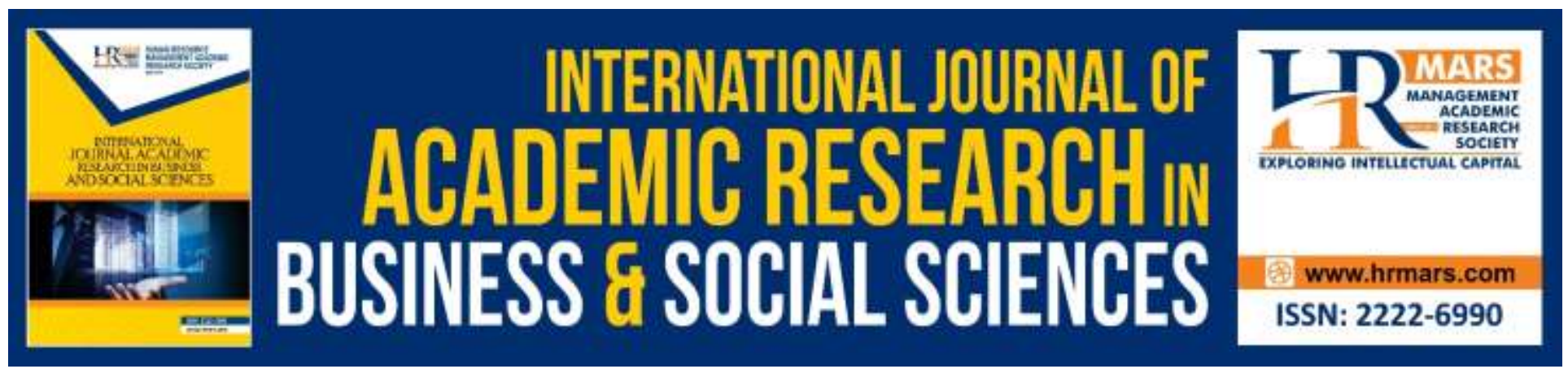

\title{
The Usage of Interactive Multimedia- Based Modules to Improve Students' Vocabulary
}

\author{
Tracy Valerian, Norjietta Binti Taisin \\ Fakulti Bahasa Dan Komunikasi, Universiti Pendidikan Sultan Idris Tg Malim, Perak, Malaysia. \\ Email: tracyvalerian03@gmail.com
}

\begin{abstract}
Vocabulary is a very important element in learning the Kadazandusun language. If students does not have sufficient vocabulary, students will face difficulty in understanding the language either in written form or in communication during Kadazandusun language teaching and learning sessions, and difficulty in mastering other language skills too. In that regard, this study was conducted to identify the usage of interactive multimedia-based modules in teaching and learning to enhance student vocabulary, especially in the Kadazandusun language subject. This study is a quasiexperimental study. Quantitative approaches are used in conjunction with pre- and post-test instruments. A total of 40 Year Four students at a school in Tambunan District were the sample of this study, divided into controlled groups (20 people) and treatment groups (20 people). The results showed that there were significant differences in the improvement of vocabulary among the pupils under controlled group and treatment group before and after the teacher uses the interactive multimedia module with a mean pre-test mean score of 3.45 and a mean post-test mean 7.25 whereas for pre-test mean values of the treatment group. is 3.05 and the mean test value is 8.15. Implications of the study show that using interactive multimedia-based modules can be a platform for students to learn vocabulary and can help teachers in adding teaching aids for Kadazandusun language subjects. In conclusion, learning methods using interactive multimedia-based modules are effective in order to improve students' vocabulary.
\end{abstract}

Keywords: Vocabulary, Interactive, Multimedia, Kadazandusun, Module.

\section{Introduction}

In line with today's technological advances, the integration of multimedia technology in the classroom is an integral part of 21st century learning. This is because the use of multimedia technology is said to change how people learn and how to obtain information. Kamarul Azman (2011) also stated that the use of multimedia technology can stimulate and motivate students to learn well and effectively. Therefore, the production of ABBM based on multimedia technology is very important in teaching and learning the vocabulary of Kadazandusun as stated by Zainal Abiden (2010) during the PdP process. 
INTERNATIONAL JOURNAL OF ACADEMIC RESEARCH IN BUSINESS AND SOCIAL SCIENCES Vol. 10, No. 6, June, 2020, E-ISSN: 2222-6990 @ 2020 HRMARS

\section{Problem Statement}

The implementation of the Bundu-Liwan dialect as a standard language in the teaching of Kadazandusun languages in schools including textbooks and activity books has made it difficult for students to master the subject especially in vocabulary. Mezah (2013) states that inadequate vocabulary can affect reading comprehension, fluency and writing skills because language proficiency is closely related to the amount of vocabulary mastered. In addition, this will also cause students to feel frustrated, less confident, scared and embarrassed if they make a mistake in speaking. Other problems related to vocabulary include the use of incorrect vocabulary in speech, the use of unnecessary vocabulary and the neglect of vocabulary that should be present in sentence structure.

The study of Rashid, Norhashimah and Othman (2012) which examined the use of interactive multimedia on reading skills among the Reading and Writing Program (PROBIM) students found that the use of interactive multimedia improves reading skills performance. However, this study focused only on the use of interactive multimedia on reading skills and not on multimedia-based learning modules. Therefore, the interactive multimedia based module is a learning tool that will be used in this study to improve student vocabulary achievement in Kadazandusun. In addition, to plan teaching and learning based on multimedia technology in line with the seventh aspiration in the Malaysian Education Development Plan (PPPM), which is to leverage Information and Communication Technology (ICT) in education.

\section{Methodology}

Quantitative study design was used in this study using experimental quazi method based on pre and post test. According to Fraenkel and Wallen (2012), a quantitative study design was performed to obtain data in numerical form that could be translated into systematic analysis to see the results. This is in line with the purpose of this study which is to evaluate the impact of the use of interactive multimedia-based modules on student achievement in vocabulary. A total of 40 students were involved in the study, which was divided into two groups, the control group and the experimental group. The control group will be taught with traditional teaching techniques while the experimental group will use interactive multimedia-based modules. Both groups will undergo pre- and post-test. Descriptive statistics analysis will be used to obtain standard mean and standard deviation for control groups and experimental groups of students in response to pre- and post-test questions. Grade scores for the control and experimental groups are reported in terms of grades, which is the most common method of reporting test results in Malaysian primary schools. Scores obtained by students in the test are conducted in the following grades:

Grades and score in Malaysian schools

\begin{tabular}{cc}
\hline Gred & Markah (\%) \\
\hline A & $80-100$ \\
\hline B & $65-79$ \\
\hline C & $50-64$ \\
\hline D & $40-49$ \\
\hline E & $0-39$ \\
\hline
\end{tabular}

(Ministry of Education Malaysia, 2016) 
INTERNATIONAL JOURNAL OF ACADEMIC RESEARCH IN BUSINESS AND SOCIAL SCIENCES Vol. 10, No. 6, June, 2020, E-ISSN: 2222-6990 @ 2020 HRMARS

Based on the score range above, the researchers analyzed the achievement scores before and after the experimental group students were exposed to interactive multimedia-based module learning materials and the control group students only participated in traditional teaching and learning sessions.

\section{Comparison of Pre and Post Test Scores for Control Groups}

Table 1 shows the comparison scores of pre- and post-test results for the control group. The total score for each test is nine. From the mean obtained for the pre test obtained by the control group was $M=3.45$ and the mean for the post test increased to $M=7.25$. There was a difference between pre- and post-test results in this control group of 3.8 .

Table 1

Comparison of Pre and Post Test Scores for Control Groups

\begin{tabular}{|c|c|c|c|c|}
\hline Student & Pre-test scores & Grade & $\begin{array}{c}\text { Post-test } \\
\text { scores }\end{array}$ & Grade \\
\hline 1 & $44 \%$ & $\mathrm{D}$ & $100 \%$ & $A$ \\
\hline 2 & $44 \%$ & $\mathrm{D}$ & $100 \%$ & A \\
\hline 3 & $44 \%$ & $D$ & $67 \%$ & $B$ \\
\hline 4 & $44 \%$ & $D$ & $67 \%$ & $B$ \\
\hline 5 & $33 \%$ & $E$ & $56 \%$ & $\mathrm{C}$ \\
\hline 6 & $44 \%$ & $\mathrm{D}$ & $78 \%$ & $B$ \\
\hline 7 & $22 \%$ & $E$ & $78 \%$ & $B$ \\
\hline 8 & $22 \%$ & $E$ & $78 \%$ & $B$ \\
\hline 9 & $44 \%$ & $\mathrm{D}$ & $89 \%$ & $A$ \\
\hline 10 & $33 \%$ & $E$ & $89 \%$ & $A$ \\
\hline 11 & $56 \%$ & $\mathrm{C}$ & $89 \%$ & $A$ \\
\hline 12 & $44 \%$ & $D$ & $89 \%$ & $A$ \\
\hline 13 & $56 \%$ & $\mathrm{C}$ & $89 \%$ & $A$ \\
\hline 14 & $22 \%$ & $E$ & $78 \%$ & $\mathrm{~B}$ \\
\hline 15 & $22 \%$ & $E$ & $67 \%$ & $B$ \\
\hline 16 & $44 \%$ & $\mathrm{D}$ & $89 \%$ & A \\
\hline 17 & $33 \%$ & $E$ & $78 \%$ & $B$ \\
\hline 18 & $56 \%$ & $\mathrm{C}$ & $100 \%$ & $A$ \\
\hline 19 & $22 \%$ & $E$ & $67 \%$ & $B$ \\
\hline 20 & $22 \%$ & $E$ & $67 \%$ & $B$ \\
\hline Min & 3.45 & & 7.25 & \\
\hline$S P$ & 1.050 & & 1.164 & \\
\hline
\end{tabular}

Table 1 shows the range of scores for the pre- and post-control control groups. The information obtained from this table shows that in the pre-test no students received grades $A$ and $B$. Only three out of 20 students received grade $C$ with the same score of $56 \%$. A total of eight students which are student number 1 until student number four, student number six, student number nine, student number twelve and student number nineteen received grade D with score $44 \%$ and $22 \%$. Nine 
INTERNATIONAL JOURNAL OF ACADEMIC RESEARCH IN BUSINESS AND SOCIAL SCIENCES Vol. 10, No. 6, June, 2020, E-ISSN: 2222-6990 @ 2020 HRMARS

students received grade $E$ with score of $33 \%$ and $22 \%$. They are the fifth, seventh, eighth, tenth, fourteenth, fifteenth, seventeenth, nineteenth and twentieth students.

Therefore, it can be concluded that in the pre-test group of 20 students, only two students achieved an average grade of $56 \%$ or grade $C$ and eight people scored $44 \%$ who reached the minimum level of pre-test. The rest did not reach the minimum with $33 \%$ and $22 \%$. However, the pupils in control group began to show improvement in post-test where nine students which are the first, second, ninth, tenth, 11th, 12th, 13th, 13th -16 , and $18^{\text {th }}$ students scored $89 \%$ and $100 \%$. There are ten students who were in a good academic standing that scored $67 \%$ and $78 \%$. They are the third, fourth, sixth, seventh, eighth, 14th, 15th, 17th, 19th and 20th students. Only one student reached the satisfactory level which is in the fifth student. In conclusion, all control students who attended teacher teaching and learning sessions using traditional techniques, namely Chalk and Talk, showed a good improvement in post-mastering of Kadazandusun vocabulary.

\section{Comparison of Pre-test and Post-Test Scores for Experimental Groups}

Table 2 shows the comparison scores of pre- and post-test results for the experimental group. The total score for each test is nine. From the mean obtained for the pre test obtained by the experimental group is $M=3.05$ and the mean for the post test increased to $M=8.15$. There was a difference between pre- and post-test results in this experimental group, 5.1, which was significantly different from the pre- and post-control group values.

Table 2

Comparison of Pre-test and Post-Test Scores for Experimental Groups

\begin{tabular}{ccccc}
\hline Student & Pre-test scores & Grade & Post-test scores & Grade \\
\hline 1 & $44 \%$ & $\mathrm{D}$ & $100 \%$ & $\mathrm{~A}$ \\
\hline 2 & $56 \%$ & $\mathrm{C}$ & $89 \%$ & $\mathrm{~A}$ \\
\hline 3 & $0 \%$ & $\mathrm{E}$ & $56 \%$ & $\mathrm{C}$ \\
\hline 4 & $44 \%$ & $\mathrm{D}$ & $89 \%$ & $\mathrm{~A}$ \\
\hline 5 & $44 \%$ & $\mathrm{D}$ & $56 \%$ & $\mathrm{C}$ \\
\hline 6 & $22 \%$ & $\mathrm{E}$ & $100 \%$ & $\mathrm{~A}$ \\
\hline 7 & $56 \%$ & $\mathrm{C}$ & $100 \%$ & $\mathrm{~A}$ \\
\hline 8 & $33 \%$ & $\mathrm{E}$ & $100 \%$ & $\mathrm{~A}$ \\
\hline 9 & $44 \%$ & $\mathrm{D}$ & $100 \%$ & $\mathrm{~A}$ \\
\hline 10 & $44 \%$ & $\mathrm{D}$ & $89 \%$ & $\mathrm{~A}$ \\
\hline 11 & $33 \%$ & $\mathrm{E}$ & $100 \%$ & $\mathrm{~A}$ \\
\hline 12 & $22 \%$ & $\mathrm{E}$ & $100 \%$ & $\mathrm{~A}$ \\
\hline 13 & $22 \%$ & $\mathrm{E}$ & $100 \%$ & $\mathrm{~A}$ \\
\hline 14 & $22 \%$ & $\mathrm{E}$ & $78 \%$ & $\mathrm{~B}$ \\
\hline 15 & $11 \%$ & $\mathrm{E}$ & $67 \%$ & $\mathrm{~B}$ \\
\hline 16 & $\mathrm{D}$ & $89 \%$ & $\mathrm{~A}$ \\
\hline 17 & $44 \%$ & $\mathrm{E}$ & $100 \%$ & $\mathrm{~A}$ \\
\hline 18 & $33 \%$ & $\mathrm{C}$ & $100 \%$ & $\mathrm{~A}$ \\
\hline 19 & $56 \%$ & $\mathrm{E}$ & $100 \%$ & $\mathrm{~A}$ \\
\hline 20 & $22 \%$ & $\mathrm{E}$ & $100 \%$ & $\mathrm{~A}$ \\
\hline $\mathrm{Min}$ & $22 \%$ & & 1.348 & \\
\hline $\mathrm{SP}$ & 3.05 & & & \\
\hline & 1.395 & & & \\
\hline
\end{tabular}


Table 2 shows the range of scores for pre- and post-test for the experimental group. The information obtained from this table shows that in the pre-test also no students received grade A and B. Only three out of 20 students received grade $C$ and all of them scored $56 \%$. Six students received grade $D$ with score of $44 \%$. The students are the first, fourth, fifth, ninth, tenth, and 16th. A total of 11 students received grade $E$ with score of $33 \%, 22 \%, 11 \%$ and $0 \%$. They are the third, sixth, eighth, 11th, 12th, 13th, 14th, 15th, 17th, 19th and 20th student. In all of the 20 students in the experimental group, only three achieved a satisfactory $56 \%$ score and six of them achieved a minimum of $44 \%$ on the pre-test. The rest did not reach the minimum with a score of 0-39\%.

However, pupils in the experimental group began to show improvement in the post-test where 16 students scored $89 \%$ and $100 \%$. They are the first, second, fourth, sixth, seventh, eighth, ninth, tenth, 11th, 12th, 13th, 16th, 17th, 18th, 19th and 20th. There are two pupils which are the $14^{\text {th }}$ and the $15^{\text {th }}$ students who achieved good achievement with the score of $67 \%$ and $78 \%$, respectively. Another two students are in the satisfactory level which are the third and fifth students. In conclusion, all students in the experimental group showed high levels of achievement after the group underwent treatment with teaching and learning using interactive multimedia-based modules.

\section{Conclusion}

Based on the above data analysis, it can be concluded that the use of interactive multimedia based modules can improve student achievement in Kadazandusun vocabulary. This clearly indicates that students in the experimental group using the interactive multimedia-based module achieved higher performance than the control group. The use of interactive multimedia based modules certainly has a positive impact on vocabulary learning. In addition, through the use of interactive multimediabased modules educators can also enhance their skills in using multimedia technology as well as increase ABBM for Kadazandusun language subjects. In addition, students can train themselves in the use of multimedia technology through the use of such modules and thus produce IT literacy students. Therefore, it is recommended that educators design creative teaching and learning on the subject of Kadazandusun language using multimedia technology to attract students to learn the language.

\section{References}

Jamian, A. R., and Hashim, N., \& Othman, S. (2012) Multimedia interaktif mempertingkatkan pembelajaran kemahiran membaca murid-murid probim. Jurnal Pendidikan Bahasa melayu ;Malay Language Education (MyLEJ), 2 (2). pp. 46-53. ISSN 2180-4842

Mezah, C. R., \& Norhayuza. (2013). Kosa Kata Teori dan Aplikasi. Serdang: Penerbit Universiti Putra Malaysia.

Frankel, J., Wallen, N., \& Huyn, H. (2012). How to design and evaluate research in education (ed. ke8). New York: Mc Graw Hill, Inc.

Kementerian Pendidikan Malaysia. (2016). Julat Markah Sekolah Rendah. Retrieved From https://mypt3.com/gred-upsr-terkini-markah

Noordin, H. S., \& Abiden, Z. N. F. (2010). Tahap Penggunaan Bahan Bantu Mengajar Dalam Kalangan Bakal Guru Fizik Semasa Latihan Mengajar. Fakulti Pendidikan. Universiti Teknologi Malaysia. 